\title{
THE Fas COUNTERATTACK:
}

\section{A MOLECULAR MECHANISM OF TUMOR IMMUNE PRIVILEGE}

\author{
Joe O'Connell,* Michael W. Bennett,* Gerald C. O'Sullivan, ${ }^{\dagger}$ \\ J. Kevin Collins, ${ }^{*}$ and Fergus Shanahan* \\ Departments of ${ }^{*}$ Medicine and ${ }^{\dagger}$ Surgery, National University of \\ Ireland, Cork, Ireland
}

FasR (Apo-1/CD95) is a cell surface receptor that mediates apoptotic cell death upon engagement, either by its natural ligand (FasL) or by agonistic, anti-FasR monoclonal antibodies (1). Fas-mediated apoptosis is involved in several regulatory functions within the immune system, including thymocyte clonal deletion and tolerance acquisition (2), T cell activation-induced cell death (3), and immune response termination (4). FasL is also a major mediator of $\mathrm{T}(5-7)$ and natural killer (NK) (8) cell cytotoxicity, by inducing apoptosis in Fas-sensitive target cells.

As many lymphoid and nonlymphoid malignancies express FasR, such tumors might be expected to be targets for FasL-mediated cytotoxicity. Although early work showing mouse xenograft tumor killing by anti-Fas, agonistic antibody treatment suggested anti-tumor potential $(9-11)$, subsequently, many tumor cells have been shown to be resistant to Fas-mediated apoptosis. Several molecular mechanisms of Fas resistance have been elucidated.

Originally, FasL was thought to be expressed only in cells of lymphoid/myeloid series-initially $\mathrm{T}(12)$ and subsequently NK (8) cells, B (13) cells, and neutrophils (14). FasL was also shown to be expressed in the cells of certain organs, such as the eye (15) and testis (16), where it mediates immune privilege by inducing apoptosis in infiltrating proinflammatory immunocytes.

A "Fas counterattack" mechanism of immune escape has emerged in colon (17), melanoma (18), and liver (19) cancer cells, which are Fas-resistant but express FasL. Such tumor cells resist the FasL assault from $\mathrm{T}$ cells but express

To whom correspondence and reprint requests should be addressed: Fergus Shanahan, Department of Medicine, Clinical Sciences Building, University Hospital, Cork, Ireland. Tel: 35321 901225; Fax: 35321 345300; e-mail: FShanahan@iruccvax.ucc.ie. their own FasL which may delete anti-tumor $\mathrm{T}$ cells by Fas-mediated apoptosis (Fig. 1). Hence, cancer cells can advance beyond the defensive measure of Fas resistance, to the offensive expression of a lethal death signal to which cytotoxic T cells (CTL) are inherently sensitive: FasL.

\section{FaS-RESISTANT TUMORS: WHY THE Fas DEATH SIGNAL FAILS}

Most studies of cell lines and freshly isolated tumor cells of diverse lymphoid and nonlymphoid origin have revealed that most cancer cells are resistant to Fas-mediated apoptosis $(17,20-$ 29). In many instances, the counterpart normal cell is Fas-sensitive, suggesting acquisition of Fas resistance at some stage of the transformation process. Molecular mechanisms of Fas resistance in tumor cells have been identified at several levels of Fas signal transduction.

Many cancer cells fail to receive the FasL apoptotic signal due to deletion or down-regulation of FasR $(17-19,30)$, or expression of antagonistic soluble FasR lacking a transmembrane domain (31-34). Lymphoma cells that have deleted the intracytoplasmic domain of FasR (35) have been isolated, precluding functional interaction with the signal-transducing proteins that normally associate with this domain, such as Fasassociated death domain protein (FADD) (36), receptor-interacting protein (RIP) (37), Fas-associated factor-1 (FAF-1) (38), and FADD-like interleukin-1 $\beta$ converting enzyme (FLICE) (39). Some cancer cells have been found to express high levels of proteins, such as Fas-associated phosphatase-1 (FAP-1) $(26,40)$ and sentrin $(41)$, which interact negatively with FasR.

Fas signaling involves sequential activation of members of the interleukin- $1 \beta$ converting enzyme (ICE) family of cysteine proteases (42-44), leading to an apoptotic proteolytic cascade. 


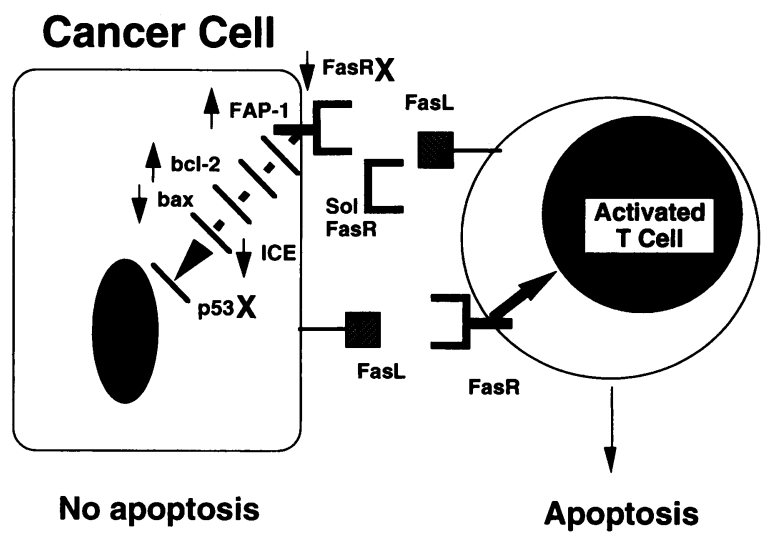

FIG. 1. The Fas counterattack

The cancer cell resists FasL-mediated T cell cytotoxicity due to up- $(\uparrow)$ or down- $(\downarrow)$ regulation or mutation $(X)$ of genes that regulate the Fas apoptotic pathway, or to expression of soluble FasR (SolFasR). The cancer cell counterattacks by expressing its own FasL, which rapidly induces apoptosis in activated $\mathrm{T}$ cells.

Down-regulation of ICE itself has been shown to result in Fas resistance in breast carcinoma cells (29) and the monoblastic leukemia cell line U937 (45). Fas sensitization of these cells in response to interferon- $\gamma$ (IFN- $\gamma$ ) was concomitant with up-regulation of ICE.

The level of expression of hematopoietic cell protein tyrosine phosphatase (HCP) correlated with Fas sensitivity in 11 human and murine lymphoid cancer cell lines (46). In the Fas-resistant human $\mathrm{T}$ cell leukemic line MOLT-4, expression of recombinant HCP restored its sensitivity to Fas.

In many cell types, interaction between the related B cell lymphoma leukemia-2 (bcl-2) and bcl-2 associated $X$ (bax) proteins regulates response to diverse apoptotic stimuli, including Fas (47). The bcl-2:bax ratio acts as a molecular rheostat controlling the cell's apoptotic propensity. Up-regulation of the anti-apoptotic protein bcl-2 has been found in many tumors and has been implicated in Fas resistance in many cancer cell lines $(48,49)$. Conversely, underexpression of its proapoptotic antagonist bax has been implicated in the Fas resistance of breast cancers (50). Fas sensitivity was restored to breast carcinoma cell lines by transfection of the bax gene (51).

Some studies show that tumor-suppressor gene mutations may impair Fas signaling. Transfection of functional wild-type $\mathrm{p} 53$ enhanced Fas sensitivity in p53-mutant colon (52), small-cell lung carcinoma, and erythroleukemia (53) cell lines. Fas engagement results in activation of the Ras oncoprotein in lymphoid cells, and a dominant-negative mutant Ras inhibited Fas signaling in these cells. The oncogenic fusion protein bcrabl expressed in chronic myelogenous leukemias (CML) and the $a b l$ oncogene itself were shown to be inhibitory to Fas-mediated apoptosis (54).

\section{FROM THE DEFENSIVE TO THE OFFENSIVE: FaSL AND TUMOR IMMUNE PRIVILEGE}

A role for FasL as a mediator of immune privilege was first demonstrated in two mouse organs: the eye (15) and the testis (16). In both cases, FasL expression was shown to cause apoptotic cell death of any proinflammatory cells that infiltrated these tissues. FasL's role in immune privilege at these sites was confirmed using mutant FasR-negative lpr (lymphoproliferative) and FasL-negative gld (generalized disease) mice. In the $l p r$ mouse, FasL expression in the retina failed to preclude inflammatory infiltration by Fas-insensitive lymphocytes. While FasL expressed in mouse Sertoli cells permitted transplant of testis tissue to syngeneic and even allogeneic hosts, this immune privilege was lost when testis from the gld mouse was transplanted to syngeneic hosts. In addition, rodent pancreatic islet allograft survival was shown to be enhanced by cotransplantation with FasL-expressing testicular cells (55) or myoblasts expressing recombinant FasL (56). Corneal allograft survival also depends on FasL expression (57).

In cancer, FasL expression was detected in lymphomas and leukemias (58). This was not unexpected since these malignancies are derived from cells that normally express FasL upon activation. The possibility that FasL might be expressed by nonlymphoid tumors as a mediator of immune escape was initially raised by the finding that some colon cancer cell lines expressed FasL (17). Subsequently, melanoma cell lines and metastatic lesions (18), and hepatocellular carcinomas (19) were also reported to express FasL. Elevated soluble FasL was immunologically detected in the serum of one-third of malignant melanoma patients. In all cases, evidence was provided that the tumor-expressed FasL was functional, as the tumor cells induced apoptosis in Fas-sensitive, but not Fas-resistant, cocultured lymphoid target cells.

Resistance to Fas-mediated apoptosis is a 
prerequisite to FasL expression by tumor cells, as otherwise, autocrine cell suicide or juxtracrine cell death would occur. In all the examined melanoma and hepatocellular carcinoma tumors and cell lines, FasR was either down-regulated or absent. Although the colon cancer cell lines expressed abundant levels of FasR, they were resistant to Fas due to signal transduction defects (17).

\section{Fas COUNTERATTACK IN TUMOR IMMUNE PRIVILEGE: IN VIVO EVIDENCE}

In addition to the demonstration of Fas-mediated killing of lymphocyte target cells by FasL-expressing tumor cells in vitro, apoptosis has also been demonstrated in situ in regions containing tumor-infiltrating lymphocytes (TIL) adjacent to FasL-positive tumor cells in surgically resected melanomas (18) and hepatocellular carcinomas (19).

Experiments using a murine FasL-expressing melanoma cell line injected into various murine host strains provided evidence for a role for FasL in delaying tumor rejection (18). When this cell line was injected into syngeneic host mice, they all developed palpable tumors. In syngeneic hosts carrying the Fas lpr mutation, only half of the mice showed tumors 6 days postinjection. The syngeneic-lpr mice were more effective in clearance of the FasL-positive tumor cells, ostensibly due to the insensitivity of their lymphocytes to the tumor's FasL. Subsequent to Day 6, differences in tumor size became less pronounced between both groups of hosts, indicating that FasLpositive tumor formation was delayed rather than prevented in FasR-negative mice.

The FasL-positive murine melanoma cell line also established tumors in an allogeneic host strain, MRL. Five days postinjection, all MRL mice had growing tumors, whereas $70 \%$ of MRL-lpr mice were devoid of tumors. These results suggest that FasL contributed significantly to the immune privilege of the melanoma tumor, although other immune escape mechanisms allowed the eventual establishment of tumors in FasL-insensitive lpr mutant mice.

\section{ATTACK-THE BEST FORM OF DEFENSE?}

Resistance to Fas alone is probably of limited advantage to the development and growth of tumors. Although some studies suggest a tumor- suppressor role for FasR $(59,60)$, evidence suggests that perforin-based rather than FasL-mediated $\mathrm{T}$ cell cytotoxicity is more important in antitumor immune surveillance (61).

Molecular defects downstream in the Fas pathway, however, may effect resistance to multiple inducers of apoptosis that share later steps in apoptotic induction. The T cell cytotoxic proteases granzyme A (62) and B (63) have been found to have ICE-like activity. Cisplatin appears to act through an ICE-dependent cell death pathway (64). In the U937 leukemia cell line, IFN- $\gamma$ caused enhanced sensitivity to anti-tumor mediators of apoptosis in addition to Fas, including gamma-irradiation and the chemotherapeutic agents etoposide and adriamycin (45). Hence, apoptotic defects at or downstream from ICE may mediate tumor resistance not only to $\mathrm{T}$ and NK cells' principal cytotoxic armaments (FasL and perforin-delivered granzymes) but also to ICE-dependent chemotherapeutic drugs. Similarly, up-regulation of bcl-2 $(48,49,65)$ or its homolog, bcl-xL $(66,67)$, or down-regulation of bax (51) has been found to confer tumor resistance to multiple apoptotic inducers. Recent evidence suggests that some cytotoxic drugs may act by stimulation of autocrine or paracrine Fas-mediated tumor cell apoptosis. Doxorubicin was shown to up-regulate FasL in leukemic cell lines (68) and bleomycin up-regulated both FasL and FasR in the hepatoma cell line HepG2 (69). In both cell types, drug-induced apoptosis was Fasmediated and apparently p53-dependent. Fasresistant cell lines were also drug-resistant.

As most tumor cells probably exhibit some degree of susceptibility to cell-mediated cytotoxic immune assaults (most tumor cells, for example, are efficiently killed by lymphokine-activated killer (LAK) cells in vitro [70]), expression of a molecule that defuses anti-tumor immune challenge would conceptually be of immense advantage to the tumor cell. FasL is such a molecule. As an established mediator of immune privilege in some normal tissues, growing evidence now supports its role as a mediator of immune privilege in tumors of diverse origin. In addition, FasL could theoretically facilitate the establishment of tumors or tumor metastases in tissues where the indigenous normal cells are themselves Fas-sensitive. In this regard, it is of interest that one FasL-expressing colon cancer cell line (SW620) was derived from a lymph node metastasis (17). Also, all melanoma metastases examined expressed FasL (18). 


\section{THE Fas COUNTERATTACK: A TARGET FOR CANCER THERAPY?}

Disarming of the Fas counterattack may offer potential as a goal for therapeutic intervention. Although Fas sensitivity has been restored to diverse cancer cell lines in vitro by transfection of several genes, including FasR (71), HCP (46), ICE (29), bax (51), and $p 53(52,53)$, it is difficult to envisage application of these approaches to therapy at present. IFN- $\gamma$ administration might sensitize some tumors to FasL $(29,72,73)$. Regression of Fas-sensitive mouse xenograft tumors in response to systemically infused agonistic antiFasR monoclonal antibodies $(9,11,63)$ was confounded by anti-FasR lethality to the liver and other Fas-sensitive organs $(74,75)$. Although monoclonal antibodies are available which block FasL function (58), tumor-targeting would probably be required for efficacy. An alternative strategy may be to render patient lymphocytes Fas-resistant. FasR-specific antisense oligonucleotides were found to protect Jurkat $\mathrm{T}$ cells from FasL expressed by colon cancer cells in vitro (17), suggesting a potential therapeutic application of antisense to FasR.

\section{REFERENCES}

1. Nagata S, Golstein P. (1995) The Fas death factor. Science 267: 1449-1456.

2. Yonehara S, Nishimura Y, Kishil S, et al. (1994) Involvement of apoptosis antigen Fas in clonal deletion of human thymocytes. Int. Immunol. 6: 1849-1856.

3. Alderson MR, Tough TW, Davis-Smith T, et al. (1995) Fas ligand mediates activation-induced cell death in human T lymphocytes. $J$. Exp. Med. 181: 71-77.

4. Daniel PT, Krammer PH. (1994) Activation induces sensitivity toward APO-1 (CD95)mediated apoptosis in human B cells. J. Immunol. 152: 5624-5632.

5. Ju ST, Cui H, Panka DJ, Ettinger R, MarshakRothstein A. (1994) Participation of target Fas protein in apoptosis pathway induced by CD4+ Thl and CD8+ cytotoxic T cells. Proc. Natl. Acad. Sci. U.S.A. 91: 4185-4189.

6. Berke G. (1995) The CTL's kiss of death. Cell 81: $9-12$.

7. Stalder T, Hahn S, Erb P. (1994) Fas antigen is the major target molecule for $\mathrm{CD} 4+\mathrm{T}$ cell-mediated cytotoxicity. J. Immunol. 152: 1127-1133.
8. Montel AH, Bochan MR, Hobbs JA, Lynch DA, Brahmi Z. (1995) Fas involvement in cytotoxicity mediated by human NK cells. Cell. Immunol. 166: 236-246.

9. Trauth BC, Klas C, Peters AMJ, et al. (1989) Monoclonal antibody-mediated tumor regression by induction of apoptosis. Science 245: 301-305.

10. Coney LR, Daniel PT, Sanborn D, et al. (1994) Apoptotic cell death induced by a mouse-human anti-APO-1 chimeric antibody leads to tumor regression. Int. J. Cancer 58: $562-567$.

11. Lucking-Famira KM, Daniel PT, Möller P, Krammer PH, Debatin KM. (1994) APO-1 (CD95) mediated apoptosis in human T-ALL engrafted in SCID mice. Leukemia 8: 18251833.

12. Suda T, Okazaki T, Naito Y, et al. (1995) Expression of the Fas ligand in cells of $\mathrm{T}$ cell lineage. J. Immunol. 154: 3806-3813.

13. Hahne $M$, Renno $T$, Schroeter $M$, et al. (1996) Activated B cells express functional Fas ligand. Eur. J. Immunol. 26: 721-724.

14. Liles WC, Kiener PA, Ledbetter JA, Aruffo A, Klebanoff SJ. (1996) Differential expression of Fas (CD95) and Fas ligand on normal human phagocytes: Implications for the regulation of apoptosis in neutrophils. J. Exp. Med. 184: 429-440.

15. Griffith TS, Brunner T, Fletcher SM, Green DR, Ferguson TA. (1995) Fas ligand-induced apoptosis as a mechanism of immune privilege. Science 270: 1189-1192.

16. Bellgrau D, Gold D, Selawry H, Moore J, Franzusoff A, Duke RC. (1995) A role for CD95 ligand in preventing graft rejection. Nature 377: 630-632.

17. O'Connell J, O'Sullivan GC, Collins JK, Shanahan F. (1996) The Fas counterattack: Fas-mediated $\mathrm{T}$ cell killing by colon cancer cells expressing Fas ligand. J. Exp. Med. 184: 1075-1082.

18. Hahne M, Rimoldi D, Schroter $M$, et al. (1996) Melanoma cell expression of Fas(Apo-1/CD95) ligand: Implications for tumor immune escape. Science 274: 13631366.

19. Strand S, Hofmann WJ, Hug H, et al. (1996) Lymphocyte apoptosis induced by CD95 (Apo-1/Fas) ligand-expressing tumor cells-a mechanism of immune evasion? Nat. Med. 2: 1361-1366.

20. Robertson MJ, Manley TJ, Pichert G, et al. (1995) Functional consequences of APO-1/ 
Fas (CD95) antigen expression by normal and neoplastic hematopoietic cells. Leuk. Lymphoma. 17: 51-61.

21. Kotani T, Aratake Y, Kondo S, Tamura K, Ohtaki S. (1994) Expression of functional Fas antigen on adult T-cell leukemia. Leuk. Res. 18: 305-310.

22. Massaia $M$, Borrione $P$, Attisano $C$, et al. (1995) Dysregulated Fas and Bcl-2 expression leading to enhanced apoptosis in $\mathrm{T}$ cells of multiple myeloma patients. Blood 85: 3679-3687.

23. Westendorf JJ, Lammert JM, Jelinek DF. (1995) Expression and function of Fas (APO1/CD95) in patient myeloma cells and myeloma cell lines. Blood 85: 3566-3576.

24. Shima Y, Nishimoto N, Ogata A, Fujii Y, Yoshizaki K, Kishimoto T. (1995) Myeloma cells express Fas antigen/APO-1 (CD95) but only some are sensitive to anti-Fas antibody resulting in apoptosis. Blood 85: 757-764.

25. Hata H, Matsuzaki H, Takeya M, et al. (1995) Expression of Fas/Apo-1 (CD95) and apoptosis in tumor cells from patients with plasma cell disorders. Blood 86: 1939-1945.

26. Mori S, Murakami-Mori K, Jewett A, Nakamura S, Bonavida B. (1996) Resistance of AIDS-associated Kaposi's sarcoma cells to Fas-mediated apoptosis. Cancer Res. 56: 1874-1879.

27. Owen-Schaub LB, Radinsky R, Kruzel E, Berry K, Yonehara S. (1994) Anti-Fas on nonhematopoietic tumors: Levels of Fas/ APO-1 and bcl-2 are not predictive of biological responsiveness. Cancer Res. 54: 15801586.

28. Weller M, Frei K, Groscurth P, Krammer PH, Yonekawa Y, Fontana A. (1994) Anti-Fas/ APO-1 antibody-mediated apoptosis of cultured human glioma cells. Induction and modulation of sensitivity by cytokines. J. Clin. Invest. 94: 954-964.

29. Keane MM, Ettenberg SA, Lowrey GA, Russell EK, Lipkowitz S. (1996) Fas expression and function in normal and malignant breast cell lines. Cancer Res. 56: 4791-4798.

30. Möller P, Koretz K, Leithauser F, et al. (1994) Expression of APO-1 (CD95), a member of the NGF/TNF receptor superfamily, in normal and neoplastic colon epithelium. Int. J. Cancer 57: 371-377.

31. Knipping E, Debatin K-M, Stricker K, Heilig B, Edar A, Krammer PH. (1995) Identification of soluble APO- 1 in supernatants of human B- and T-cell lines and increased serum levels in B- and T-cell leukemias. Blood 85: 1562-1569.

32. Owen-Schaub LB, Angelo LS, Radinsky R, Ware CF, Gesner TG, Bartos DP. (1995) Soluble Fas/APO-1 in tumor cells: A potential regulator of apoptosis? Cancer Lett. 94: 1-8.

33. Tachibana $O$, Nakazawa $H$, Lampe J, Watanabe K, Kleihues P, Ohgaki H. (1995) Expression of Fas/APO-1 during the progression of astrocytomas. Cancer Res. 55: 5528-5530.

34. Natoli G, Ianni A, Costanzo A, et al. (1995) Resistance to Fas-mediated apoptosis in human hepatoma cells. Oncogene 11: 1157-1164.

35. Cascino I, Papoff G, De Maria R, Testi R, Ruberti G. (1996) Fas/Apo-1 (CD95) receptor lacking the intracytoplasmic signaling domain protects tumor cells from Fas-mediated apoptosis. J. Immunol. 156: 13-17.

36. Chinnaiyan AM, O'Rourke $\mathrm{K}$, Tewari $M$, Dixit VM. (1995) FADD, a novel death domain-containing protein, interacts with the death domain of Fas and initiates apoptosis. Cell 81: 505-512.

37. Stanger BZ, Leder P, Lee TH, Kim E, Seed B. (1995) RIP: A novel protein containing a death domain that interacts with Fas/APO-1 (CD95) in yeast and causes cell death. Cell 81: 513-523.

38. Chu K, Niu X, Williams LT. (1995) A Fasassociated protein factor, FAF1, potentiates Fas-mediated apoptosis. Proc. Natl. Acad. Sci. U.S.A. 92: 11894-11898.

39. Muzio M, Chinnaiyan AM, Kischkel FC, et al. (1996) FLICE, a novel FADD-homologous ICE/CED-3-like protease, is recruited to the CD95 (Fas/APO-1) death-inducing signaling complex. Cell 85: 817-827.

40. Sato T, Irie S, Kitada S, Reed JC. (1995) FAP-1: A protein tyrosine phosphatase that associates with Fas. Science 268: 411-415.

41. Okura T, Gong L, Kamitani T, et al. (1996) Protection against Fas/Apo-1 and tumor necrosis factor-mediated cell death by a novel protein, sentrin. J. Immunol. 157: 4277-4281.

42. Enari M, Talanian RV, Wong WW, Nagata S. (1996) Sequential activation of ICE-like and CPP32-like proteases during Fas-mediated apoptosis. Nature 380: 723-726.

43. Los $M$, van de Craen M, Penning LC, et al. (1995) Requirement of an ICE/CED-3 protease for Fas/APO-1-mediated apoptosis. $\mathrm{Na}$ ture 375: 81-83.

44. Srinivasula SM, Ahmad M, Fernandes-Alnemri T, Litwack G, Alnemri ES. (1996) Mo- 
lecular ordering of the Fas-apoptotic pathway: The Fas/APO-1 protease Mch5 is a CrmA-inhibitable protease that activates multiple Ced-3/ICE-like cysteine proteases. Proc. Natl. Acad. Sci. U.S.A. 93: 14486-14491.

45. Tamura T, Ueda S, Yoshida M, Matsuzaki $M$, Mohri H, Okubo T. (1996) IFN-gamma induces ICE gene expression and enhances cellular susceptibility to apoptosis in the U937 leukemia cell line. Biochem. Biophys. Res. Commun. 229: 21-26.

46. Su X, Zhou T, Wang Z, Yang P, Jope RS, Mountz JD. (1995) Defective expression of hematopoietic cell protein tyrosine phosphatase (HCP) in lymphoid cells blocks Fas-mediated apoptosis. Immunity 2: 353-362.

47. Itoh N, Tsujimoto Y, Nagata S. (1993) Effect of bcl-2 on Fas antigen-mediated cell death. J. Immunol. 151: 621-627.

48. Weller M, Malipiero U, Aguzzi A, Reed JC, Fontana A. (1995) Protooncogene bcl-2 gene transfer abrogates Fas/APO-1 antibody-mediated apoptosis of human malignant glioma cells and confers resistance to chemotherapeutic drugs and therapeutic irradiation. J. Clin. Invest. 95: 2633-2643.

49. Jaattela $M$, Benedict $M$, Tewari $M$, Shayman JA, Dixit VM. (1995) Bcl-x and bcl-2 inhibit TNF and Fas-induced apoptosis and activation of phospholipase A2 in breast carcinoma cells. Oncogene 10: 2297-2305.

50. Bargou RC, Daniel PT, Mapara MY, et al. (1995) Expression of the bcl-2 gene family in normal and malignant breast tissue: Low bax-alpha expression in tumor cells correlates with resistance towards apoptosis. Int. J. Cancer 60: 854-859.

51. Bargou RC, Wagener C, Bommert $\mathrm{K}$, et al. (1996) Overexpression of the death-promoting gene bax-alpha which is downregulated in breast cancer restores sensitivity to different apoptotic stimuli and reduces tumor growth in SCID mice. J. Clin. Invest. 97: 2651-2659.

52. Tamura T, Aoyama N, Saya H, et al. (1995) Induction of Fas-mediated apoptosis in p53transfected human colon carcinoma cells. Oncogene 11: 1939-1946.

53. Owen-Schaub LB, Zhang W, Cusack JC, et al. (1995) Wild-type human p53 and a temperature-sensitive mutant induce Fas/ APO-1 expression. Mol. Cell Biol. 15: 30323040.

54. McGahon AJ, Nishioka WK, Martin SJ, Mahboubi A, Cotter TG, Green DR. (1995)
Regulation of the Fas apoptotic cell death pathway by Abl. J. Biol. Chem. 270: 2262522631.

55. Korbutt GS, Elliott JF, Rajotte RV. (1997) Cotransplantation of allogeneic islets with allogeneic testicular cell aggregates allows long-term graft survival without systemic immunosuppression. Diabetes 46: 317-322.

56. Lau HT, Yu M, Fontana A, Stoeckert CJ, Jr. (1996) Prevention of islet allograft rejection with engineered myoblasts expressing FasL in mice. Science 270: 109-1 12.

57. Stuart PM, Griffith TS, Usui N, Pepose J, Yu X, Ferguson TA. (1997) CD95 ligand (FasL)induced apoptosis is necessary for corneal allograft survival. J. Clin. Invest. 99: 396-402.

58. Tanaka M, Suda T, Haze K, et al. (1996) Fas ligand in human serum. Nat. Med. 2: $317-$ 322.

59. Zornig M, Grzeschiczek A, Kowalski MB, Hartmann KU, Moroy T. (1995) Loss of Fas/ Apo-1 receptor accelerates lymphomagenesis in E mu L-Myc transgenic mice but not in animals infected with MoMuLV. Oncogene 10: 2397-2401.

60. Peng SL, Robert ME, Hayday AC, Craft J. (1996) A tumor-suppressor function for Fas (CD95) revealed in T cell-deficient mice. $J$. Exp. Med. 184: 1149-1154.

61. van den Broek ME, Kagi D, Ossendorp F, et al. (1996) Decreased tumor surveillance in perforin-deficient mice. J. Exp. Med. 184: 1781-1790.

62. Irmler M, Hertig S, MacDonald HR, et al. (1995) Granzyme A is an interleukin 1 betaconverting enzyme. J. Exp. Med. 181: 19171922.

63. Quan LT, Caputo A, Bleackley RC, Pickup DJ, Salvesen GS. (1995) Granzyme B is inhibited by the cowpox virus serpin cytokine response modifier A. J. Biol. Chem. 270: 10377-10379.

64. Kondo S, Barna BP, Morimura $\mathrm{T}$, et al. (1995) Interleukin-1 $\beta$ converting enzyme mediates cisplatin-induced apoptosis in malignant glioma cells. Cancer Res. 55: 61666171.

65. Schroter M, Lowin B, Borner C, Tschopp J. (1995) Regulation of Fas(Apo-1/CD95)- and perforin-mediated lytic pathways of primary cytotoxic T lymphocytes by the protooncogene bcl-2. Eur. J. Immunol. 25: 3509-3513.

66. Minn AJ, Rudin CM, Boise LH, Thompson CB. (1995) Expression of bcl-xL can confer a 
multi-drug resistance phenotype. Blood 86: 1903-1910.

67. Schott AF, Apel IJ, Nunez G, Clarke MF. (1995) Bcl-xL protects cancer cells from p53mediated apoptosis. Oncogene 11: 1389-1394.

68. Friesen C, Herr I, Krammer PH, Debatin K-M. (1996) Involvement of the CD95 (APO-1/Fas) receptor/ligand system in druginduced apoptosis in leukemia cells. Nat. Med. 2: 574-577.

69. Müller M, Strand S, Hug H, et al. (1997) Drug-induced apoptosis in hepatoma cells is mediated by the CD95 (APO-1/Fas) receptor/ligand system and involves activation of wild-type p53. J. Clin. Invest. 99: 403-413.

70. Rayner AA, Grimm EA, Lotze MT. (1985) Lymphokine-activated killer (LAK) cells: Analysis of factors relevant to the immunotherapy of human cancer. Cancer 55: 13271333.

71. Weller M, Malipiero U, Rensing-Ehl A, Barr PJ, Fontana A. (1995) Fas/APO-1 gene trans- fer for human malignant glioma. Cancer Res. 55: 2936-2944.

72. Browning JL, Miatkowski K, Sizing I, et al. (1996) Signaling through the lymphotoxinbeta receptor induces the death of some adenocarcinoma tumor lines. J. Exp. Med. 183: 867-878.

73. Abreu-Martin MT, Vidrich A, Lynch DH, Targan SR. (1995) Divergent induction of apoptosis and IL-8 secretion in HT-29 cells in response to TNF-alpha and ligation of Fas antigen. J. Immunol. 155: 4147-4154.

74. Ogasawara J, Watanabe-Fukunaga R, Adachi $M$, et al. (1993) Lethal effect of the antiFas antibody in mice. Nature 364: 806-809.

75. Rodriguez I, Matsuura K, Ody C, Nagata S, Vassalli P. (1996) Systemic injection of a tripeptide inhibits the intracellular activation of CPP32-like proteases in vivo and fully protects mice against Fas-mediated fulminant liver destruction and death. J. Exp. Med. 184: 2067-2072. 